\title{
EFFICIENCY OF FOREIGN EXCHANGE MARKETS: A DEVELOPING COUNTRY PERSPECTIVE
}

\author{
Guneratne B Wickremasinghe \\ Department of Econometrics \& Business Statistics \\ Monash University, Cualfield Victoria, 3145 Australia \\ e-mail: guneratne.wickremasinghe@buseco.monash.edu.au
}

\begin{abstract}
This study tests weak and semi-strong form efficiency of the foreign exchange market in Sri Lanka during the recent float using six bilateral exchange rates. Weak-form efficiency is examined using unit root tests while semi-strong form efficiency is tested using cointegration, Granger causality tests and variance decomposition analysis. Results indicate that the Sri Lankan foreign exchange market is consistent with the weak-form of the efficient market hypothesis (EMH). However, the results provide evidence against the semi-strong version of the EMH. These results have important implications for government policy makers and participants in the foreign exchange market of Sri Lanka.
\end{abstract}

Keywords: efficient market hypothesis (EMH), Sri Lanka, foreign exchange market, Japanese yen, variance decomposition

JEL Classifications: F31, G14

\section{ACKNOWLEDGEMENTS}

The author wishes to thank Mrs R. Dheerasinghe of the Central Bank of Sri Lanka for providing the data and two anonymous referees of this journal for their very valuable comments to improve the paper. However, all errors remain the sole responsibility of the author.

\section{INTRODUCTION}

The efficient market hypothesis (EMH) originally due to Fama (1965) asserts that in an efficient market, prices always fully reflect available information. EMH has three forms; weak, semi-strong and strong reflecting different degrees of information. When a market is weak-form efficient, its prices reflect all the information available in the past prices or returns. Semi-strong form has the prices of financial assets instantly reflecting publicly available information. Lastly, in a strong-form efficient market, prices of financial assets reflect even inside information. Accordingly, in an efficient market, participants cannot use 
(i) past prices or returns of a financial asset, (ii) publicly available information or (iii) information available to the insiders of the market to devise any rule to beat the market consistently. The strong form of the EMH encompasses both weak and semi-strong versions of the EMH.

Since the publication of Fama's seminal work, foreign exchange markets especially in developed countries, have been extensively tested for efficiency using different econometric techniques (Cumby \& Obstfeld, 1984; Taylor, 1988; Edwards, 1983; Hakkio \& Rush, 1989; Taylor \& MacDonald, 1989; Singh, 1997; Serletis, 1997). Recently there have been several studies which provide mixed evidence in this area using data from developing countries (Masih \& Masih, 1996; Sarwa, 1997; Los, 1999).

The efficiency or otherwise of a foreign exchange market has policy implications of enormous importance (Pilbeam, 1992). If a foreign exchange market is inefficient, a model that best predicts exchange rate movements can be developed. Therefore, an inefficient foreign exchange market provides opportunities for profitable foreign exchange transactions. Further, in an inefficient foreign exchange market, the government authorities can determine the best way to influence exchange rates, reduce exchange rate volatility and evaluate the consequences of different economic policies. Alternatively, a foreign exchange market that is efficient needs minimal government intervention and its participants cannot make abnormal gains from foreign exchange transactions.

To the knowledge of the author, there are no previous empirical studies on the applicability of EMH to the Sri Lankan foreign exchange market. The objective of this paper is to test the efficiency of the Sri Lankan foreign exchange market during the recent floating exchange rate regime. Forward exchange rates are not published by the Central Bank of Sri Lanka as the market for forward contracts is not yet well developed. Therefore, the scope of the study is limited to the efficiency of the spot foreign exchange market. Weak-form efficiency is tested using unit root tests. Semi-strong form efficiency is examined using three techniques: cointegration, Granger causality and variance decomposition analysis. Test of strong-form efficiency is a topic for future research.

The remainder of the paper will be divided into econometric methodology followed by the data and empirical results and ends with the conclusion.

\section{ECONOMETRIC METHODOLOGY}

Empirical tests of foreign exchange market efficiency have been carried out using different econometric techniques. These methodologies have mainly aimed at 
determining whether (a) a spot exchange rate behaves as a random walk (Liu \& He, 1991; Bleaney, 1998), (b) the forward exchange rate is an unbiased predictor of future spot exchange rate (Norrbin \& Refferett, 1996; Wesso, 1999; Barnhart, McNown, \& Wallace, 1999; Zacharatos \& Sutcliff, 2002) or (c) whether there is a cointegrating relationship among a set of spot exchange rates (Masih \& Masih, 1996; Sanchez-Fung, 1999; Speight \& McMillan, 2001).

This paper adopts Engle and Granger (EG) (1987) and Johansen (1991, 1995) cointegration tests. These procedures are carried out in two steps. The first step in the analysis tests for the order of integration of the variables. Order of integration refers to the number of times a variable is differenced before becoming stationary. A condition applicable to above tests is that the variables entering the cointegrating equation should be integrated of the same order. To test the degree of integration of the variables, two well-known tests are used in this paper. The first test is the Augmented Dickey-Fuller (ADF) $(1979,1981)$ test and the second test is the Phillips-Perron (PP) (1988) test. These unit root tests provide evidence on whether the exchange rates follow random walks. Therefore, they are also a test of the weak-form of the EMH.

According to Engle and Granger (1987), if two variables are cointegrated, there exists a long-run equilibrium relationship between them. In the EG method, cointegration is tested by regressing one variable on the other and testing whether the residuals of the estimated regression equation are stationary. In this paper, ADF and PP tests are used to test the stationarity of the residuals obtained from the bivariate cointegration equations.

The Johansen cointegration test is based on the following vector autoregression equation:

$$
y_{t}=A_{1} y_{t-1}+\ldots+A_{p} y_{t-p}+B x_{t}+\varepsilon_{t}
$$

where $y_{t}$ is a $k$-vector of non-stationary $I(1)$ variables, $x_{t}$ is a vector of deterministic variables and $\varepsilon_{t}$ is a vector of innovations.

In making inferences about the number of cointegrating relations, two statistics known as trace statistic and maximal eigenvalue statistic are used. The trace statistic tests the null hypothesis that there are at most $r$ cointegrating vectors against the alternative hypothesis of $r$ or more cointegrating vectors. Meanwhile, in the maximal eigenvalue statistic test the null hypothesis of $r$ cointegrating vectors is tested against the alternative of $r+1$ cointegrating vectors. To make inferences regarding the number of cointegrating relationships, trace and 
maximum eigenvalue statistics are compared with the critical values tabulated in Osterwald-Lenum (1992).

If two variables are cointegrated, there exists an error-correction model of the following form (Engle \& Granger, 1987):

$$
\begin{aligned}
& \Delta x_{t}=a_{1}+b_{1} e c t_{t-1}+\sum_{i=1}^{m} c_{1} \Delta x_{t-i}+\sum_{i=1}^{n} d_{1} \Delta y_{t-i}+e_{1 t} \\
& \Delta y_{t}=a_{2}+b_{2} e c t_{t-1}+\sum_{i=1}^{m} c_{2} \Delta y_{t-i}+\sum_{i=1}^{n} d_{2} \Delta x_{t-i}+e_{2 t}
\end{aligned}
$$

where $x_{t}$ and $y_{t}$ are the variables which are cointegrated, $\Delta$ is the difference operator, $m$ and $n$ are the lag lengths of the variables, ect are the residuals from the cointegrating equations and $e_{1 t}$ and $e_{2 t}$ are white-noise residuals.

The error-correction model opens up another channel of causality through the error-correction term that is ignored in standard Granger causality tests. Therefore, causality can also be tested by examining the statistical significance of (i) the error-correction term by a separate t-test; (ii) by testing the joint significance of the lags of each explanatory variable by an $F$ or Wald $\chi^{2}$ test; or (iii) by a test of error-correction terms and lagged terms of each explanatory variable simultaneously by a joint $F$ or Wald $\chi^{2}$ test.

Granger causality test results can be used to test causality within the sample period only. Therefore, to make inferences on causality beyond the sample period, the variance decomposition analysis is used. In the variance decomposition analysis, the variance of the forecast error of a particular variable is partitioned into proportions attributable to innovations (or shocks) in each variable in the system including its own. If a variable can be optimally forecast from its own lags, then it will have all its forecast variance accounted for by its own disturbances (Sims, 1982).

\section{DATA AND EMPIRICAL RESULTS}

Data used in this paper consist of average monthly nominal spot exchange rates for Japanese yen (JPY), the UK pound (GBP), the US dollar (USD), French franc (FRF), Indian rupee (INR) and German mark (DM) for the period January 1986 to November 2000. These nominal exchange rates were selected for analysis in this paper as they were the only exchange rates available in the Monthly Bulletins published by the Central Bank of Sri Lanka during the sample period. 
TABLE 1

AUGMENTED DICKEY-FULLER (ADF) TEST RESULTS FOR UNIT ROOTS

\begin{tabular}{c|c|c|c|c}
\hline \multirow{2}{*}{ Currency } & \multicolumn{2}{|c|}{ Level } & \multicolumn{2}{c}{ First differences } \\
\cline { 2 - 5 } & Intercept & Intercept and trend & Intercept & Intercept and trend \\
\hline DM & $-2.834(4)$ & $-1.736(4)$ & $-6.779(3)^{\mathrm{a}}$ & $-7.262(3)^{\mathrm{a}}$ \\
GBP & $-2.006(7)$ & $-2.592(2)$ & $-9.545(1)^{\mathrm{a}}$ & $-9.606(1)^{\mathrm{a}}$ \\
FRF & $-2.488(4)$ & $-1.566(4)$ & $-6.701(3)^{\mathrm{a}}$ & $-7.081(3)^{\mathrm{a}}$ \\
INR & $-1.420(1)$ & $-1.542(1)$ & $-10.137(0)^{\mathrm{a}}$ & $-10.136(0)^{\mathrm{a}}$ \\
JPY & $-1.438(6)$ & $-2.310(11)$ & $-7.683(5)^{\mathrm{a}}$ & $-7.736(5)^{\mathrm{a}}$ \\
USD & $-0.138(2)$ & $-2.198(2)$ & $-8.343(1)^{\mathrm{a}}$ & $-8.320(1)^{\mathrm{a}}$ \\
\hline
\end{tabular}

Notes:

1. a implies significance at the $1 \%$ level.

2. DM, GBP, FRF, INR, JPY and USD denote the nominal exchange rates for German mark, Sterling pound, French franc, Indian rupee, Japanese yen and the US dollar, respectively.

3. ADF statistic is obtained by $\Delta x_{t}=a_{0}+b_{0} x_{t-1}+\sum_{i=1}^{k} c_{0} \Delta x_{t-1}+w_{t}$ where $\Delta$ is the difference operator, $a_{0}, b_{0}$ and $c_{0}$ are coefficients to be estimated, $x$ is the variable whose time series properties are examined and $w$ is the white-noise error term.

4. The lags of the dependent variable used to obtain white-noise residuals are determined using Akaike Information Criterion (AIC).

5. The null and the alternative hypotheses are respectively $b_{0}=0$ (series is non-stationary) and $b_{0}<0$ (series is stationary).

6. As the coefficient $b_{0}$ has a non-standard distribution, it is compared with critical values tabulated by MacKinnon (1991).

Table 1 reports the results of the ADF unit root test for the six nominal exchange rates for levels and the first differences of the natural log values. Interestingly all exchange rates under consideration are non-stationary in their levels and become stationary when they are first differenced. The level of significance of the ADF statistics for all currencies is $1 \%$. These results are consistent with the weak-form of the EMH that says financial time series behave as random walks. In other words, past exchange rates cannot be used to predict future exchange rates. Therefore, the participants in the foreign exchange market cannot devise any statistical technique to gain from foreign exchange market transactions consistently.

Table 2 reports the results of the PP unit root test for the six exchange rates. The PP test produces results similar to those of ADF test, except for the German mark exchange rate. However, the ADF regression for this currency has a lower AIC (Akaike Information Criterion) value. Therefore, on this basis, this variable can be considered as having a random walk. The level of significance of the PP statistics is $1 \%$ for all currencies. These results again confirm the earlier results of 
the ADF test indicating that the foreign exchange rates in Sri Lanka behave as random walks providing support for the weak-form of the EMH.

TABLE 2

PHILLIPS-PERRON (PP) TEST RESULTS FOR UNIT ROOTS

\begin{tabular}{c|c|c|c|c}
\hline \multirow{2}{*}{ Currency } & \multicolumn{2}{|c|}{ Level } & \multicolumn{2}{c}{ First differences } \\
\cline { 2 - 5 } & Intercept & Intercept and trend & Intercept & Intercept and trend \\
\hline DM & $-3.136^{\mathrm{a}}$ & -1.996 & $-9.218^{\mathrm{a}}$ & $-9.449^{\mathrm{a}}$ \\
GBP & -1.817 & -2.672 & $-10.127^{\mathrm{a}}$ & $-10.168^{\mathrm{a}}$ \\
FRF & -2.664 & -1.703 & $-9.843^{\mathrm{a}}$ & $-10.016^{\mathrm{a}}$ \\
INR & -1.363 & -1.444 & $-10.052^{\mathrm{a}}$ & $-10.044^{\mathrm{a}}$ \\
JPY & -2.013 & -2.975 & $-9.411^{\mathrm{a}}$ & $-9.418^{\mathrm{a}}$ \\
USD & -0.081 & -2.153 & $-7.516^{\mathrm{a}}$ & $-7.494^{\mathrm{a}}$ \\
\hline
\end{tabular}

Notes:

1. a implies significance at the $1 \%$ level.

2. See note 2 of Table 1 for details of notations in column one.

3. PP test suggests a non-parametric method of controlling for higher order autocorrelation in a series and is based on the following first order autoregressive [AR(1)] process: $\Delta y_{t}=\alpha+\beta y_{t-1}+\varepsilon_{t}$ where $\Delta$ is the difference operator, $\alpha$ is the constant, $\beta$ is the slope and $y_{t-1}$ is the first lag of the variable $y$. This paper uses Newey-West (1987) method.

4. The null and the alternative hypotheses tested are the same as for the ADF test.

5. Figures in brackets indicate the number of lags of the dependent variable used in the PP regression to obtain white-noise residuals. Lag truncation for Bartlett kernal is 4 for all the currencies for levels and first differences. The truncation lags were determined using Newey-West (1994) method.

One requirement of the EG and Johansen techniques is that for there to be a cointegrating relationship, variables under consideration should be integrated of the same order. Therefore, all exchange rates being integrated of the same order allows us to carry out EG cointegration test as well as the Johansen cointegration test.

Table 3 reports the results of the EG test for cointegration. In column one all the possible pairs of currencies that can be used to test for cointegration are shown. With each pair, the first currency shown has been regressed on the second currency to obtain the residuals on which ADF and PP tests are performed. Column three of the table reports the ADF test statistics to test for the stationarity of residuals from each regression equation. According to the results, nine cointegration equations (30\%) have white-noise residuals. This means that there is a cointegrating relationship between the currencies in each of these pairs. The co-movement between currencies indicates that one of the currencies in the pair can be predicted from the other currency. Therefore, such co-movements indicate a violation of the semi-strong form EMH. If a foreign currency market is efficient 
TABLE 3

ENGLE-GRANGER (EG) COINTEGRATION TEST RESULTS

\begin{tabular}{cccc}
\hline $\begin{array}{c}\text { Dependent } \\
\text { variable }\end{array}$ & $\begin{array}{c}\text { Independent } \\
\text { variable }\end{array}$ & $\begin{array}{c}\text { ADF } \\
\text { test statistic }\end{array}$ & $\begin{array}{c}\text { PP } \\
\text { test statistic }\end{array}$ \\
\hline DM & GBP & $-1.409(1)$ & -1.546 \\
& FRF & $-3.310(3)^{\mathrm{b}}$ & $-4.252^{\mathrm{a}}$ \\
& INR & $-3.157(1)^{\mathrm{b}}$ & $-3.087^{\mathrm{b}}$ \\
& JPY & $-1.759(1)$ & -1.423 \\
& USD & $-1.941(1)$ & -2.030 \\
GBP & DM & $-1.073(1)$ & -1.042 \\
& FRF & $-1.225(3)$ & -1.043 \\
& INR & $-1.718(2)$ & -1.892 \\
& JPY & $-1.881(1)$ & -1.801 \\
FRF & USD & $-3.059(1)^{\mathrm{b}}$ & $-3.030^{\mathrm{b}}$ \\
& DM & $-3.153(3)^{\mathrm{b}}$ & $-4.105^{\mathrm{a}}$ \\
& GBP & $-1.583(3)$ & -1.345 \\
& INR & $-2.902(1)^{\mathrm{b}}$ & $-2.848^{\mathrm{c}}$ \\
& JPY & $-2.044(3)$ & -1.501 \\
INR & USD & $-1.873(3)$ & -1.723 \\
& DM & $-2.834(1)^{\mathrm{b}}$ & $-2.679^{\mathrm{b}}$ \\
& GBP & $-2.012(1)$ & -1.828 \\
& FRF & $-2.719(1)^{\mathrm{c}}$ & $-2.579^{\mathrm{c}}$ \\
& JPY & $-2.330(1)$ & -2.225 \\
& USD & $-1.658(1)$ & -1.518 \\
JPY & DM & $-1.352(1)$ & -1.018 \\
& GBP & $-1.722(1)$ & -1.811 \\
& FRF & $-1.705(3)$ & -1.266 \\
& INR & $-2.242(1)$ & $-2.286^{\mathrm{c}}$ \\
& USD & $-2.675(1)^{\mathrm{c}}$ & $-2.916^{\mathrm{b}}$ \\
& DM & $-1.103(1)$ & -1.028 \\
& GBP & $-2.972(1)^{\mathrm{b}}$ & $-2.670^{\mathrm{c}}$ \\
& FRF & $-0.979(1)$ & -0.907 \\
& INR & $-1.053(1)$ & -0.788 \\
& JPY & $-2.342(1)$ & -2.462 \\
\hline & & & \\
& & & \\
& & &
\end{tabular}

Notes:

1. a, b and c imply significance at the $1 \%, 5 \%$ and $10 \%$ level, respectively.

2. See note 2 of Table 1 for details of notations in columns one and two.

3. Columns one and two report respectively the dependent and independent variables of each cointegration equation. Lags of the dependent variable in the ADF regressions were selected using AIC. Figures in brackets against ADF statistics in column three are the number of lags of the dependent variable used to obtain whitenoise residuals. Truncation lag for each PP regression was 4 and was selected using the Newey-West method. 
in the semi-strong form, exchange rates at a particular point in time reflect all the available information. Available information includes information available in exchange rates other than the one with which we are concerned.

Column four of Table 3 reports the PP test statistics to test whether the regressions of pairs of currencies in column one contain stationary residuals or whether currencies in each pair are cointegrated. The results are consistent with those of the ADF test except that one additional pair of currencies is cointegrated (Japanese yen and Indian rupee, when the former is regressed on the latter).

Johansen's test results for each possible pair of currencies are reported in Table 4 . Results reported for trace and maximum eigenvalue tests in columns five and six, respectively indicate that there are only two cointegrating relationships: (i) between German mark and French franc; and (ii) the UK pound and Japanese yen. The cointegrating relationship between German mark and French franc is significant at the $1 \%$ level and that between the UK pound and the Japanese yen is significant at the $5 \%$ level. These results indicate that around $98 \%$ (28 pairs out of 30) of the exchange rate pairs are not cointegrated. Therefore, these results provide strong evidence that the Sri Lankan foreign exchange market is efficient in the semi-strong sense.

TABLE 4

JOHANSEN COINTEGRATION TEST RESULTS FOR EACH POSSIBLE PAIR OF CURRENCIES

\begin{tabular}{|c|c|c|c|c|c|}
\hline $\begin{array}{c}\text { Pairs of } \\
\text { currencies }\end{array}$ & $\begin{array}{l}\text { Number of } \\
\text { lags in VAR }\end{array}$ & $\begin{array}{c}\text { Trend } \\
\text { assumption }\end{array}$ & $\begin{array}{c}\text { Null } \\
\text { hypothesis }\end{array}$ & $\begin{array}{c}\text { Trace } \\
\text { statistic }\end{array}$ & $\begin{array}{l}\text { Maximal } \\
\text { eigenvalue } \\
\text { statistic }\end{array}$ \\
\hline \multirow[t]{2}{*}{$\mathrm{DM} / \mathrm{GBP}$} & \multirow[t]{2}{*}{2} & \multirow[t]{2}{*}{1} & $r=0$ & 16.376 & 13.225 \\
\hline & & & $r \leq 1$ & 3.152 & 3.152 \\
\hline \multirow[t]{2}{*}{ DM/FRF } & \multirow[t]{2}{*}{4} & \multirow[t]{2}{*}{1} & $r=0$ & $30.155^{\mathrm{a}}$ & $21.098^{\mathrm{a}}$ \\
\hline & & & $r \leq 1$ & 9.057 & 9.057 \\
\hline \multirow[t]{2}{*}{ DM/INR } & \multirow[t]{2}{*}{2} & \multirow[t]{2}{*}{3} & $r=0$ & 18.012 & 12.548 \\
\hline & & & $r \leq 1$ & 5.464 & 5.464 \\
\hline \multirow[t]{2}{*}{ DM/JPY } & \multirow[t]{2}{*}{5} & \multirow[t]{2}{*}{2} & $r=0$ & 12.559 & 10.723 \\
\hline & & & $r \leq 1$ & 1.836 & 1.836 \\
\hline \multirow[t]{2}{*}{ DM/USD } & \multirow[t]{2}{*}{3} & \multirow[t]{2}{*}{2} & $r=0$ & 9.235 & 9.220 \\
\hline & & & $r \leq 1$ & 0.015 & 0.015 \\
\hline \multirow[t]{2}{*}{ GBP/FRF } & \multirow[t]{2}{*}{2} & \multirow[t]{2}{*}{1} & $r=0$ & 13.969 & 11.659 \\
\hline & & & $r \leq 1$ & 2.310 & 2.310 \\
\hline \multirow[t]{2}{*}{ GBP/INR } & \multirow[t]{2}{*}{6} & \multirow[t]{2}{*}{2} & $r=0$ & 13.004 & 10.050 \\
\hline & & & $r \leq 1$ & 2.954 & 2.954 \\
\hline \multirow[t]{2}{*}{ GBP/JPY } & \multirow[t]{2}{*}{5} & \multirow[t]{2}{*}{2} & $r=0$ & 8.888 & 4.844 \\
\hline & & & $r \leq 1$ & $4.043^{\mathrm{b}}$ & $4.043^{\mathrm{b}}$ \\
\hline
\end{tabular}


TABLE 4 - (Continued)

\begin{tabular}{lcccrr}
\hline $\begin{array}{c}\text { Pairs of } \\
\text { currencies }\end{array}$ & $\begin{array}{c}\text { Number of } \\
\text { lags in VAR }\end{array}$ & $\begin{array}{c}\text { Trend } \\
\text { assumption }\end{array}$ & $\begin{array}{c}\text { Null } \\
\text { hypothesis }\end{array}$ & $\begin{array}{r}\text { Trace } \\
\text { statistic }\end{array}$ & $\begin{array}{c}\text { Maximal } \\
\text { eigenvalue } \\
\text { statistic }\end{array}$ \\
\hline GBP/USD & 3 & 2 & $r=0$ & 0.370 & 9.911 \\
& & & $r \leq 1$ & 0.459 & 0.459 \\
FRF/INR & 2 & 1 & $r=0$ & 19.508 & 13.729 \\
& & & $r \leq 1$ & 5.778 & 5.778 \\
FRF/JPY & 5 & 2 & $r=0$ & 11.844 & 9.069 \\
& & & $r \leq 1$ & 2.775 & 2.775 \\
FRF/USD & \multirow{2}{*}{2} & 2 & $r=0$ & 7.756 & 7.732 \\
& & & $r \leq 1$ & 0.023 & 0.023 \\
INR/JPY & 2 & 1 & $r=0$ & 17.733 & 13.817 \\
& & & $r \leq 1$ & 3.916 & 3.916 \\
INR/USD & \multirow{2}{*}{2} & 2 & $r=0$ & 3.253 & 3.246 \\
& & & $r \leq 1$ & 0.007 & 0.007 \\
JPY/USD & 7 & 2 & $r=0$ & 6.482 & 6.336 \\
& & & $r \leq 1$ & 0.146 & 0.146 \\
\hline
\end{tabular}

Notes:

1. a and b imply significance at the $1 \%$ and $5 \%$ level, respectively.

2. See note 2 of Table 1 for details of notations in column one.

3. The deterministic components are selected using the Pantula principle suggested by Johansen (1992). In the trend assumption column, 1 denotes no deterministic trend (restricted constant), 2 denotes linear deterministic trend, and 3 denotes linear deterministic trend (restricted).

4. Lag lengths in vector autoregressions were selected using Likelihood Ratio (LR) test.

5. Critical values for the trace and maximal eigenvalue test were obtained from OsterwaldLenum (1992).

Table 5 reports the Johansen test for the cointegration among the six exchange rates. The trace statistic reveals that there is one cointegrating relationship among the six exchange rates. Since the trace statistic takes into account all of the smallest eigenvalues, it possesses more power than the maximum eigenvalue statistic (Kasa, 1992; Serletis \& King, 1997). Further, Johansen and Juselius (1990) recommend the use of the trace statistic when there is a conflict between these two statistics. Therefore, this result indicates that there is a long-run comovement among these six exchange rates. In other words, the value of any currency out of the six currencies can be predicted using the values of the other currencies. This is a violation of the efficiency of the foreign exchange market in its semi-strong form. 
TABLE 5

JOHANSEN TEST RESULTS FOR COINTEGRATION AMONG THE SIX CURRENCIES

\begin{tabular}{ccccccc}
\hline $\begin{array}{c}\text { Null } \\
\text { hypothesis }\end{array}$ & $\begin{array}{c}\text { Trace } \\
\text { statistics }\end{array}$ & $\begin{array}{c}5 \% \\
\text { critical } \\
\text { value }\end{array}$ & $\begin{array}{c}1 \% \\
\text { critical } \\
\text { value }\end{array}$ & $\begin{array}{c}\text { Maximal } \\
\text { eigenvalue } \\
\text { statistics }\end{array}$ & $\begin{array}{c}5 \% \\
\text { critical } \\
\text { value }\end{array}$ & $\begin{array}{c}1 \% \\
\text { critical } \\
\text { value }\end{array}$ \\
\hline$r=0$ & $98.702^{\mathrm{b}}$ & 94.15 & 103.18 & 37.114 & 39.37 & 45.10 \\
$r \leq 1$ & 61.588 & 68.52 & 76.07 & 28.353 & 33.46 & 38.77 \\
$r \leq 2$ & 33.233 & 47.21 & 54.46 & 15.959 & 27.07 & 32.24 \\
$r \leq 3$ & 17.273 & 29.68 & 35.65 & 11.762 & 20.97 & 25.52 \\
$r \leq 4$ & 5.511 & 15.41 & 20.04 & 5.236 & 14.07 & 18.63 \\
$r \leq 5$ & 0.275 & 3.76 & 6.65 & 0.275 & 3.76 & 6.65 \\
\hline
\end{tabular}

Notes:

1. b implies significance at the $5 \%$ level.

2. See notes of Table 4 for details on selection of the trend components, trace and eigenvalue statistics and critical values.

3. Four lags were included in the vector autoregression determined by the likelihood ratio. Pantula principle selected the cointegration equation with a linear deterministic trend.

TABLE 6

TEMPORAL CAUSALITY RESULTS BASED ON THE VECTOR ERRORCORRECTION MODEL (VECM)

\begin{tabular}{c|cccccc|c}
\hline \multirow{2}{*}{$\begin{array}{c}\text { Dependent } \\
\text { variable }\end{array}$} & \multicolumn{5}{|c|}{ Short-run causality, chi-square-statistics } & $\begin{array}{c}\text { Error-correction } \\
\text { term, } t \text {-statistics }\end{array}$ \\
\cline { 2 - 8 } & $\Delta$ JPY & $\Delta$ USD & $\Delta$ INR & $\Delta$ FRF & $\Delta$ GBP & $\Delta$ DM & ECT $\left(\varepsilon_{1, t-1}\right)$ \\
\hline$\Delta$ JPY & - & 3.373 & 1.432 & 1.155 & $10.588^{\mathrm{b}}$ & 2.353 & 1.141 \\
$\Delta$ USD & 1.918 & - & $10.027^{\mathrm{b}}$ & 2.711 & 6.708 & 3.592 & -0.554 \\
$\Delta$ INR & 1.118 & $13.258^{\mathrm{a}}$ & - & 3.079 & 17.312 & 3.230 & 1.012 \\
$\Delta$ FRF & $8.054^{\mathrm{c}}$ & 7.712 & 1.282 & - & 0.636 & 6.606 & $3.055^{\mathrm{a}}$ \\
$\Delta$ GBP & 1.523 & 4.739 & 2.207 & 1.470 & - & 1.863 & $3.024^{\mathrm{a}}$ \\
$\Delta$ DM & 7.331 & 7.711 & 0.788 & 3.556 & 1.066 & - & $1.967^{\mathrm{b}}$ \\
\hline
\end{tabular}

Notes:

1. a, b and c imply significance at the $1 \%, 5 \%$ and $10 \%$ level, respectively.

2. $\Delta$ indicates the first difference. See note 2 of Table 1 for the details of other notations in column one.

3. Only one error-correction term was included in the error correction model as there was only one cointegrating relationship among the six currencies. ECTs are the estimated t-statistics testing the null hypothesis that ECTs are each statistically significant. Number of lags in the VECM was selected using the Likelihood Ratio (LR) test.

Temporal causality test results reported in Table 6 indicate three bivariate causal relationships. According to the results there is a feedback relationship between the US dollar and Indian rupee, one causal relationship from Japanese yen to the UK pound and another causal relationship from Japanese yen to the French franc. The causal relationship from the US dollar to Indian rupee is strong with a 
significance level of $1 \%$. The causal relationships from the UK pound to Japanese yen and from Indian rupee to the US dollar are significant at the $5 \%$ level. However, the causal relationship from the Japanese yen to French franc is significant only at the $10 \%$ level. The error-correction term is significant in three of the error-correction models. The causal relationship between Japanese yen and French franc is of a long-run nature as the error-correction term in the errorcorrection model for the French franc is statistically significant. Existence of causal relationships indicates the predictability of one exchange rate from one or more of the other exchange rates. Therefore, these results provide evidence against the semi-strong form of the EMH.

Table 7 reports the results of the variance decomposition analysis. This analysis was used to supplement the Granger causality test results to examine the out-ofsample causality. Results reported in columns three to eight explain how much of a spot exchange rate's own shock is explained by movements in its own variance and those of the others over the forecast horizon (i.e. 48 months). The order of the nominal exchange rates used in the analysis was as follows: US dollar (USD), Japanese yen (JPY), Indian rupee (INR), UK pound (GBP), French franc (FRF), and German mark (DEM). This order is justified considering the dominant nature of the US dollar exchange rate in the international transactions.

TABLE 7

RESULTS OF VARIANCE DECOMPOSITION OF EXCHANGE RATES

\begin{tabular}{rccccccc}
\hline \multirow{2}{*}{ Months } & \multirow{2}{*}{$\begin{array}{c}\text { Relative } \\
\text { variance in }\end{array}$} & \multicolumn{5}{c}{ Percentage of forecast variance explained by innovation in } \\
\cline { 3 - 7 } & & JPY & USD & INR & FRF & DM & GBP \\
\hline 1 & JPY & 99.97 & 0.02 & 0.00 & 0.00 & 0.00 & 0.00 \\
12 & & 94.07 & 0.60 & 1.08 & 0.21 & 1.67 & 2.37 \\
24 & & 94.69 & 0.39 & 1.04 & 0.14 & 1.31 & 2.42 \\
36 & & 94.84 & 0.32 & 1.03 & 0.12 & 1.22 & 2.45 \\
48 & & 94.93 & 0.29 & 1.03 & 0.11 & 1.17 & 2.47 \\
\hline 1 & USD & 0.00 & 100.00 & 0.00 & 0.00 & 0.00 & 0.00 \\
12 & & 1.37 & 86.76 & 0.48 & 0.08 & 5.28 & 6.02 \\
24 & & 0.83 & 85.41 & 0.38 & 0.12 & 7.32 & 5.93 \\
36 & & 0.67 & 85.00 & 0.35 & 0.13 & 7.91 & 5.94 \\
48 & & 0.58 & 84.79 & 0.33 & 0.14 & 8.22 & 5.94 \\
\hline 1 & INR & 0.40 & 11.33 & 88.26 & 0.00 & 0.00 & 0.00 \\
12 & & 2.41 & 23.21 & 63.39 & 0.48 & 4.58 & 5.92 \\
24 & & 1.30 & 27.43 & 59.82 & 0.59 & 5.64 & 5.22 \\
36 & & 0.96 & 28.67 & 58.80 & 0.63 & 5.89 & 5.05 \\
48 & & 0.78 & 29.30 & 58.28 & 0.65 & 6.02 & 4.95 \\
\hline
\end{tabular}


Guneratne B Wickremasinghe

TABLE 7 - (Continued)

\begin{tabular}{|c|c|c|c|c|c|c|c|}
\hline \multirow[t]{2}{*}{ Months } & \multirow{2}{*}{$\begin{array}{c}\text { Relative } \\
\text { variance in }\end{array}$} & \multicolumn{6}{|c|}{ Percentage of forecast variance explained by innovation in } \\
\hline & & JPY & USD & INR & FRF & DM & GBP \\
\hline 1 & FRF & 21.70 & 3.49 & 0.95 & 42.63 & 0.00 & 31.24 \\
\hline 12 & & 7.46 & 19.13 & 0.11 & 44.04 & 14.81 & 14.45 \\
\hline 24 & & 5.30 & 21.48 & 0.08 & 45.87 & 14.65 & 12.61 \\
\hline 36 & & 4.57 & 22.21 & 0.07 & 46.46 & 14.66 & 12.02 \\
\hline 48 & & 4.20 & 22.58 & 0.06 & 46.76 & 14.67 & 11.73 \\
\hline 1 & DM & 10.57 & 3.12 & 0.00 & 0.00 & 0.00 & 86.31 \\
\hline 12 & & 4.52 & 17.50 & 1.53 & 1.35 & 7.55 & 67.54 \\
\hline 24 & & 2.91 & 23.56 & 2.41 & 1.75 & 8.09 & 61.27 \\
\hline 36 & & 2.24 & 25.53 & 2.69 & 1.92 & 8.28 & 59.34 \\
\hline 48 & & 1.90 & 26.58 & 2.84 & 2.01 & 8.38 & 58.30 \\
\hline 1 & GBP & 26.21 & 2.22 & 0.42 & 36.97 & 4.76 & 29.42 \\
\hline 12 & & 11.41 & 15.59 & 0.13 & 39.09 & 18.63 & 15.14 \\
\hline 24 & & 9.76 & 16.97 & 0.13 & 40.70 & 18.20 & 14.23 \\
\hline 36 & & 9.16 & 17.42 & 0.13 & 41.22 & 18.13 & 13.92 \\
\hline 48 & & 8.87 & 17.65 & 0.13 & 41.49 & 18.09 & 13.77 \\
\hline
\end{tabular}

Notes:

1. Figures in the first column refer to months after a once-only shock. Cholesky ordering for the variance decomposition was $\log (\mathrm{USD}), \log (\mathrm{JPY}), \log (\mathrm{INR}), \log (\mathrm{GBP}), \log (\mathrm{FRF})$ and $\log (\mathrm{DM})$

2. See note 2 of Tables 1 and 6 for details of notations in column two.

3. Variance decompositions for the months 1, 12, 24, 36 and 48 only are reported. All figures in columns three through eight have been rounded to two decimal places.

According to the results reported in Table 7, Japanese yen and the US dollar explain up to $95 \%$ and $85 \%$ of their respective variances even after 48 months following the once-only shock. The other exchange rates explain a very little proportion of the variability of these two exchange rates at all time horizons considered.

When the Indian rupee exchange rate is considered, most of its variance is explained by itself. About $88 \%$ of the variability of the Indian rupee exchange rate in the first month is explained by itself. At this time horizon, US dollar exchange rate explains most of the remaining variability (around 11\%) of the Indian rupee exchange rate. The higher the time horizon, the more is the variability of the Indian rupee exchange rate explained by the US dollar exchange rate. When the time horizon is 48 months, about $29 \%$ of the variability of the Indian rupee is explained by the US dollar exchange rate. At longer time horizons, German mark and the UK pound also account for more than $5 \%$ and $4 \%$, respectively of the variability of the Indian rupee exchange rate. 
As far as the French franc exchange rate is concerned, more than $50 \%$ of its variance is accounted for by Japanese yen, the US dollar and the UK pound. However, the influence of the US dollar is more prominent at all time horizons except the first time horizon. The next two dominant currencies determining the variability of French franc exchange rate are German mark and the UK pound. When compared to the influence of the US dollar, the German mark and the UK pound, the influence of the Japanese yen on Indian rupee is not so prominent at longer time horizons.

A close perusal of the variance decomposition results for the UK pound indicates that more than $58 \%$ of its variance is accounted for by itself at all times horizons considered. However, the percentage of variability that is explained by the UK pound exchange rate goes down with the increase in the length of the time horizon. Although the Japanese yen exchange rate accounts for about $11 \%$ of the remaining variance of the UK pound in the first month, the US dollar exchange rate accounts for the variability of the UK pound at longer time horizons.

The variance decomposition results for the German mark exchange rate depict a completely different pattern when compared with those for the other exchange rates. In the first month, only about $5 \%$ of the variability of German mark exchange rate is explained by itself. At this horizon, most of German mark's variability (about 93\%) is explained by French franc, the UK pound and Japanese yen. At all other horizons, about $18 \%$ of the variability of the German mark exchange rate is explained by itself and the rest is explained by the US dollar, French franc and the UK pound exchange rates.

The above results indicate that the forecast variance of one exchange rate is explained by others revealing causal relationships between currencies. Therefore, these results do not support the semi-strong form of the EMH to Sri Lankan foreign exchange market. Such causal relationships can be used to predict the future value of one currency from the past values of one or more of the other currencies.

Overall, the results for weak-form efficiency using the ADF and PP tests indicate that the six exchange rates studied follow random walks. Therefore, the current value of an exchange rate cannot be predicted using its past values. These results are consistent with the weak-form of the efficient market hypothesis. However, the results of cointegration tests, error-correction model estimates and variance decomposition analysis indicate that the movement in one or more of the currencies can be predicted using the other exchange rates. These results are inconsistent with the efficient market hypothesis in its semi-strong form. 


\section{CONCLUSIONS}

This study examined the weak and semi-strong form efficiency of the foreign exchange market in Sri Lanka using monthly data for six currencies for the period January 1986 to November 2000. While unit root tests are used to test the weakform of the EMH, semi-strong form of the EMH is investigated using cointegration, Granger causality and variance decomposition analysis. These tests provide inconsistent results.

Results of unit root tests indicate that all six exchange rates are random walks. These results support the EMH in its weak-form. Implications of these results are that the participants in the foreign exchange market in Sri Lanka cannot devise some rule or technique that can be used to predict future movements of an exchange rate from its past values.

However, the cointegration and Granger causality tests and variance decomposition analysis provide evidence against the semi-strong version of the EMH. They indicate that the movement of one or more exchange rates can be predicted from the movements of the other exchange rates. Therefore, the participants in the foreign exchange market can engage in profitable transactions both in the short and long-run.

The exchange rate between domestic and foreign currency is a major economic policy variable. Therefore, the efficiency or otherwise of a foreign exchange market is very important for policy makers of any country. An efficient foreign exchange market indicates that a government cannot influence the movement of exchange rates as the exchange rates are not predictable. The results of this study have important policy implications as they indicate that the foreign exchange market of Sri Lanka is inefficient. The government can make informed decisions on exchange rates, take actions to reduce exchange rate volatility and evaluate the consequences of various economic policies for exchange rates. Participants in the foreign exchange market can devise various trading rules or techniques to make abnormal profits from transactions in the foreign exchange market. However, they should consider the costs involved in such activities to determine their profitability. Future researchers can corroborate the results of this study by employing other econometric techniques such as asymmetric and nonlinear models and high-frequency data. 


\section{REFERENCES}

Barnhart, S. W., McNown, R., and Wallace, M. S. (1999). Non-informative tests of the unbiased forward exchange rate. Journal of Financial and Quantitative Analysis, 34, 265-291.

Bleaney, M. (1998). Market efficiency and apparent unit roots: an application to exchange rates. Economic Record, 74, 139-144.

Cumby, R. E., and Obstfeld, M. (1984). International interest rate and price level linkages under flexible exchange rates: a review of recent evidence. In: J. F. O. Bilson, and R. C. Marston (Eds.), Exchange Rate Theory and Practice. Chicago: University of Chicago Press.

Dickey, D. A., and Fuller, W. A. (1979). Distribution for the estimates for autoregressive time series with a unit root. Journal of the American Statistical Association, 74, 427-31.

. (1981). Likelihood ratio statistics for auto-regressive time series with a unit root. Econometrica, 49, 1057-72.

Edwards, S. (1983). Floating exchange rates, expectations and new information. Journal of Monetary Economics, 11, 321-36.

Engle, R. F., and Granger, C. W. J. (1987). Cointegration and error correction representation, estimation and testing. Econometrica, 55, 251-76.

Engle, R. F., and Yoo, B. S. (1987). Forecasting and testing in cointegrated systems. Journal of Econometrics, 35, 143-159.

Fama, E. F. (1965). The behaviour of stock market prices. Journal of Business, 38, 34-105.

Hakkio, C. S., and Rush, M. (1989). Market efficiency and cointegration: an application to the sterling and deutsche mark exchange rates. Journal of International Money and Finance, 8, 75-88.

Johansen, S. (1991). Estimation and hypothesis testing of cointegration vectors in gaussian vector autoregressive models. Econometrica, 59, 1551-1580.

. (1992). Determination of cointegration rank in the presence of a linear trend. Oxford Bulletin of Economics and Statistics, 54, 383-397.

- (1995). Likelihood-based inference in cointegrated vector autoregressive models. Oxford: Oxford University Press. 
Johansen, S., and Juselius, K. (1990). Maximum likelihood estimation and inference on cointegration with applications to the demand for money. Oxford Bulletin of Economics and Statistics, 52, 169-210.

Kasa, K. (1992). Common stochastic trends in international stock markets. Journal of Monetary Economics, 29, 95-124.

Levich, R. M. (1978). Tests of forecast models of market efficiency in international money market. In: J. A. Frankel, and H. G. Johnson (Eds.), The Economics of Exchange Rates. Reading, Mass.: Addison-Wesley.

Liu, C. Y., and He, J. (1991). A variance-ratio test of random walks in foreign exchange rates. Journal of Finance, 46, 773-785.

Los, A. C. (1999). Nonparametric testing of the high-frequency efficiency of the 1997 Asian foreign exchange markets. Journal of Multinational Financial Management, 9, 265-269.

MacKinnon, J. G. (1991). Critical values for cointegration tests - chapter 13. In: R. F. Engle, and C. W. J. Granger (Eds.), Long-run Economic Relationships: Readings in Cointegration. Oxford: Oxford University Press.

Masih, A. M. M., and Masih, R. (1996). Common stochastic trends, multivariate market efficiency and the temporal causal dynamics in a system of daily spot exchange rates. Applied Financial Economics, 6, 495-504.

Newey, W., and West, K. (1987). A simple positive semi-definite, heteroskedasticity and auto-correlation consistent covariance matrix. Econometrica, 55, 703-708.

. (1994). Automatic lag selection in covariance matrix estimation. Review of Economic Studies, 61, 631-653.

Norrbin, S., and Refferett, K. (1996). Exogeneity and forward rate unbiasedness. Journal of International Money and Finance, 15, 267-274.

Osterwald-Lenum, M. (1992). A note with quantiles of the asymptotic distribution of the maximum likelihood cointegration rank test statistics. Oxford Bulletin of Economics and Statistics, 54, 461-472.

Phillips, P. C. B., and Perron, P. (1988). Testing for a unit root in time series regression. Biometrica, 75, 335-346.

Pilbeam, K. (1992). International Finance. London: The Macmillan. 
Sanchez-Fung, J. R. (1999). Efficiency of the black-market foreign exchange rates and PPP: the case of the Dominican Republic. Applied Economics Letters, 6, 173-176.

Sarwa, G. (1997). Efficiency of black markets in foreign currencies in Southeast Asia. Journal of Multinational Financial Management, 7, 333-344.

Serletis, A., and King, M. (1997). Common stochastic trends and convergence of european stock markets. The Manchester School, 65, 44-57.

Sims, C. A. (1982). Policy analysis with econometrics models. Brooking Papers on Economic Activity, 1, 107-52.

Singh, T. C. (1997). Efficiency of Australian foreign exchange market empirical evidence from cointegration tests. Indian Economic Journal, 44, 155-69.

Speight, A., and McMillan, D.G. (2001). Cointegration and predictability in prereform East European black-market exchange rates. Applied Economics Letters, 8, 775-759.

Taylor, M. P. (1988). A dynamic model of forward foreign exchange risk, with estimates for three major exchange rates. The Manchester School, 56, 55-68.

Taylor, M. P., and MacDonald, R. (1989). Exchange rate economics: an expository survey. In: M. P. Taylor, and R. MacDonald (Eds.), Exchange rates and open economy macroeconomic models. Oxford: Basil Blackwell.

Wesso, G. R. (1999). The forward rate as an optimal predictor of the future spot rate in South Africa: an Econometric Analysis. Occasional Paper No. 13, South African Reserve Bank, South Africa.

Zacharatos, N., and Sutcliff, C. (2002). Is the forward rate for the Greek Drachma unbiased? A VECM analysis with both overlapping and non-overlapping data. Journal of Financial Management and Analysis, 15, 27-37. 